report of the Quality Standards Subcommittee of the American Academy of Neurology. Neurology 2010;74:1911-1918.

4. Institute of Medicine (IOM) National Academy of Sciences. Clinical Practice Guidelines We Can Trust. Washington, DC: The National Academies Press; 2011.

5. Shafer TJ. Improving relatives' consent to organ donation. BMJ 2009;338:b701.

\section{HERPES SIMPLEX VIRUS-1 ENCEPHALITIS CAN TRIGGER ANTI-NMDA RECEPTOR ENCEPHALITIS: CASE REPORT}

Gordon J. Gilbert, St. Petersburg, FL: Leypoldt et al. ${ }^{1}$ reported an interesting case in which herpes simplex encephalitis (HSE) probably triggered the production of reactive NMDA receptor (NMDAR) antibodies. Within weeks of being treated with acyclovir for HSE, the patient had what the authors believed was recurrent HSE, yet it later proved to be NMDAR limbic encephalitis.

Since the viral encephalitic episode closely resembled the autoimmune encephalitic attack, it is difficult to know when the NMDAR limbic encephalitis first manifested. At initial discharge after having 3 weeks of acyclovir therapy, the patient had slow recovery, residual retrograde and anterograde amnesia, and impaired executive function. Some of these residua could have reflected the developing autoimmune encephalitis. The NMDAR immunoglobulin G (IgG) antibody level was 0 at day 1 but $1: 800$ by day 42 . These IgG levels might have become clinically relevant by week 3 of the illness. Following subsequent treatment with IV methylprednisolone, it would be interesting to know whether the patient's condition improved beyond initial discharge.

Since this is the first case reported, it is unclear how often NMDAR antibodies develop in the context of HSE. It is possible that joint use of antiviral and corticosteroid medications may become the standard for the treatment of herpes simplex virus considering the potential for NMDA antibodies to effect prolongation or recurrence of the limbic encephalitis.

Author Response: Frank Leypoldt, Josep Dalmau, Barcelona, Spain: Relapsing symptoms post-HSE usually occur within a few weeks and represent either a true viral relapse or a disorder postulated to be immune-mediated. This patient belonged to the second category. He did not have a true relapse of HSE, but anti-NMDAR encephalitis.

Our goal was to demonstrate a new synthesis of NMDAR antibodies that started after the viral infection. It is unclear whether some of the residual deficits from the first admission represented the initial manifestation of anti-NMDAR encephalitis. Only the relapsing symptoms responded to immunotherapy and this may suggest that the viral encephalitis caused the baseline deficits.

In recent studies with 6 additional patients, we confirmed that HSE can trigger anti-NMDAR encephalitis, usually between 4 and 6 weeks after HSE, but sometimes occurs without clear interval improvement of HSE. There are currently 13 patients reported with anti-NMDAR encephalitis as relapsing symptoms post-HSE ${ }^{2-5}$ and there is evidence that HSE triggers NMDAR antibodies., ${ }^{2,3}$ Most patients were children and developed choreoathetosis and dyskinesias, and immunotherapy seemed effective.

We agree that these findings may provide another reason to add steroids during treatment of $\mathrm{HSE}^{6}$ yet it is unclear whether this would prevent the development of anti-NMDAR encephalitis.

C 2014 American Academy of Neurology

1. Leypoldt F, Titulaer MJ, Aguilar E, et al. Herpes simplex virus-1 encephalitis can trigger anti-NMDA receptor encephalitis: case report. Neurology 2013;81:1637-1639.

2. Armangue T, Leypoldt F, Malaga I, et al. Herpes simplex virus encephalitis is a trigger of brain autoimmunity. Ann Neurol 2014;75:317-323.

3. Pruess $\mathrm{H}$, Finke C, Höltje M, et al. N-methyl-D-aspartate receptor antibodies in herpes simplex encephalitis. Ann Neurol 2012;72:902-911.

4. Mohammad SS, Sinclair K, Pillai S, et al. Herpes simplex encephalitis relapse with chorea is associated with autoantibodies to N-methyl-D-aspartate receptor or dopamine-2 receptor. Mov Disord 2014;29:117-122.

5. Hacohen Y, Deiva K, Pettingill P, et al. N-methyl-D-aspartate receptor antibodies in post-herpes simplex virus encephalitis neurological relapse. Mov Disord 2014;29:90-96.

6. Meyding-Lamade UK, Oberlinner C, Rau PR, et al. Experimental herpes simplex virus encephalitis: a combination therapy of acyclovir and glucocorticoids reduces long-term magnetic resonance imaging abnormalities. J Neurovirol 2003;9:118-125. 


\section{Neurology}

\section{Herpes simplex virus-1 encephalitis can trigger anti-NMDA receptor encephalitis: Case report}

Gordon J. Gilbert, Frank Leypoldt and Josep Dalmau

Neurology 2014;82;2041

DOI 10.1212/01.wnl.0000450946.75616.32

This information is current as of June 2, 2014

\section{Updated Information \&} Services

References

Permissions \& Licensing

Reprints including high resolution figures, can be found at: http://n.neurology.org/content/82/22/2041.full

This article cites 6 articles, 1 of which you can access for free at: http://n.neurology.org/content/82/22/2041.full\#ref-list-1

Information about reproducing this article in parts (figures,tables) or in its entirety can be found online at:

http://www.neurology.org/about/about_the_journal\#permissions

Information about ordering reprints can be found online: http://n.neurology.org/subscribers/advertise

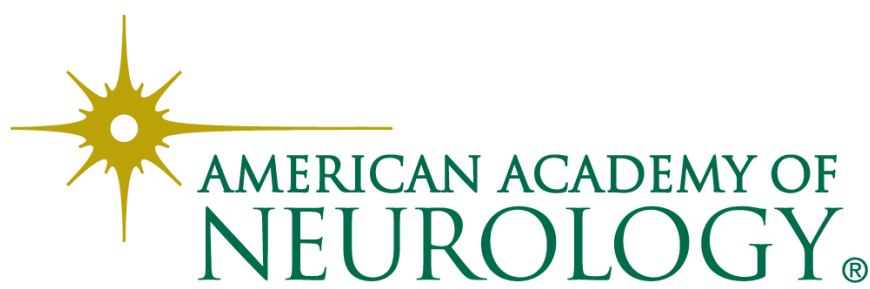

